\title{
Short communication: Lipolytic activity on milk fat by Staphylococcus aureus and Streptococcus agalactiae strains commonly isolated in Swedish dairy herds
}

\author{
Janak K. Vidanarachchi, ${ }^{*}$ Shengjie Li, $†$ Åse Sternesjö Lundh, $†$ and Monika Johansson† ${ }^{1}$ \\ *Department of Animal Science, Faculty of Agriculture, University of Peradeniya, Peradeniya, Sri Lanka 20400 \\ †Department of Food Science, Uppsala BioCenter, Swedish University of Agricultural Sciences, SE-750 07 Uppsala, Sweden
}

\begin{abstract}
The objective of this study was to determine the lipolytic activity on milk fat of 2 bovine mastitis pathogens, that is, Staphylococcus aureus and Streptococcus agalactiae. The lipolytic activity was determined by 2 different techniques, that is, thin-layer chromatography and an extraction-titration method, in an experimental model using the most commonly occurring field strains of the 2 mastitic bacteria isolated from Swedish dairy farms. The microorganisms were inoculated into bacteria-free control milk and incubated at $37^{\circ} \mathrm{C}$ to reflect physiological temperatures in the mammary gland. Levels of free fatty acids (FFA) were analyzed at time of inoculation $(t=0)$ and after 2 and $6 \mathrm{~h}$ of incubation, showing significant increase in FFA levels. After $2 \mathrm{~h}$ the FFA content had increased by approximately $40 \%$ in milk samples inoculated with Staph. aureus and Strep. agalactiae, and at $6 \mathrm{~h}$ the pathogens had increased FFA levels by $47 \%$ compared with the bacteria-free control milk. Changes in lipid composition compared with the bacteria-free control were investigated at 2 and 6 $\mathrm{h}$ of incubation. Diacylglycerols, triacylglycerols, and phospholipids increased significantly after $6 \mathrm{~h}$ incubation with the mastitis bacteria, whereas cholesterol and sterol esters decreased. Our results suggest that during mammary infections with Staph. aureus and Strep. agalactiae, the action of lipases originating from the mastitis pathogens will contribute significantly to milk fat lipolysis and thus to raw milk deterioration.
\end{abstract}

Key words: free fatty acids, bovine milk, mastitis bacteria, lipolysis, thin-layer chromatography

\section{Short Communication}

Lipases are enzymes catalyzing the hydrolysis of triglycerides (TG), the main lipid component of milk, re-

Received March 11, 2015.

Accepted August 6, 2015

${ }^{1}$ Corresponding author: monika.johansson@slu.se sulting in free, nonesterified FA (Deeth, 2006). Elevated levels of FFA are known to affect the flavor of milk negatively, giving rise to rancid off-flavor and reducing the shelf life of milk and dairy products (Shipe et al., 1980). In the raw milk, the TG will be protected from action by lipases by the milk fat globule membrane. However, instability or mechanical disruption of the milk fat globule membrane will enhance the exposure of milk fat to degradation. In fresh milk, lipolysis is catalyzed by the endogenous lipoprotein lipase as well as by exogenous, microbial lipases (Jensen and Newburg, 1995; Deeth, 2006; Hanus et al., 2008). Whereas pasteurization of the milk will inactivate lipoprotein lipase, microbial lipases may be very heat resistant, remaining active after heat treatment (Sørhaug and Stepaniak, 1997). For instance, thermostable lipolytic and proteolytic enzymes originating from psychrotrophic bacteria have been shown to cause drastic reduction in shelf life of HTST and UHT pasteurized milk during storage (Teh et al., 2011).

Staphylococcus aureus and Streptococcus agalactiae are major causes of clinical and subclinical mastitis all over the world (Riffon et al., 2001). They are contagious bacteria, adhering to and multiplying in the mammary tissue, and are frequently found in bulk-tank milk samples (Keefe, 1997; Leitner et al., 2006). In connection with mastitis, protease activity hydrolyzing the technologically important caseins and also reducing shelf life and sensory attributes of dairy products is higher in milk from quarters infected with mastitis bacteria than in milk from healthy quarters (Politis et al., 1989). Haddadi et al. (2005) suggested that Escherichia coli proteases have a direct proteolytic effect on casein. Results in our previous studies showed the same for strains of Staph. aureus and Strep. agalactiae (Åkerstedt et al., 2012; Johansson et al., 2013a). In contrast, only a limited number of studies highlight the direct contribution of mastitis bacteria on milk fat degradation. Rosenstein and Götz (2000) characterized the staphylococcal lipases, and their significance has been related to bacterial lipid metabolism and pathogenesis. Lu et al. (2012) showed that Staph. aureus, 
but also many other staphylococcal species, are able to produce FA-modifying enzymes, and some of these have also been shown to exhibit lipase activity. It has not yet been investigated to what extent lipase activity of Staph. aureus and Strep. agalactiae may affect the levels of FFA in milk and thus contribute to product deterioration. The aim of the current study was therefore to examine the lipolytic ability on milk fat of strains of the bovine mastitis pathogens Staph. aureus and Strep. agalactiae. The selected strains were a gift from the National Veterinary Institute, Uppsala, Sweden, from a nationwide survey aiming at characterization of strains of Staph. aureus and Strep. agalactiae isolated in Swedish dairy herds. The 2 strains used in this study were identified as the most commonly occurring strains of Staph. aureus and Strep. agalactiae, respectively.

Bacteriological examination was performed by accredited routine methods at the Mastitis Laboratory at National Veterinary Institute, Uppsala, Sweden, according to Hogan et al. (1999). Both strains were obtained as pure cultures initiated from single colonies in triplicates and cultured separately overnight in $5 \mathrm{~mL}$ of nutrient broth containing $10 \%$ horse serum and incubated at $37^{\circ} \mathrm{C}$. The subcultured bacterial cultures (1.5 $\mathrm{mL}$ ) were transferred to $28.5 \mathrm{~mL}$ of bacteria-free, UHT milk ( $1.5 \%$ fat) in triplicates according to the method described by Johansson et al. (2013a) and incubated at $37^{\circ} \mathrm{C}$ to reflect physiological temperatures in the udder. The milk samples were buffered with $0.1 M$ 3-morpholino-propanesulfonic acid to prevent acidification of the samples during incubation. Subsamples for analyses of FFA by the extraction-titration method were collected from the incubated UHT milk at 3 different time points $(0,2$, and $6 \mathrm{~h})$, whereas total bacteria count and $\mathrm{pH}$ were determined after $1,2,4$, and $6 \mathrm{~h}$ as previously described by $\AA$ kerstedt et al. (2012). Lipid classes were determined at 2 and $6 \mathrm{~h}$ after inoculation using highperformance thin-layer chromatography (TLC).

For the extraction-titration method, based on Salih et al. (1977), the milk fat was extracted from $20 \mathrm{~g}$ of milk with a mixture of diethyl ether and hexane (80:20, $\mathrm{vol} / \mathrm{vol}$ ) in the presence of $26 \% \mathrm{NaCl}$ and 4 droplets of $0.25 \%$ methyl orange indicator resolved in water. The samples were vortexed for $1 \mathrm{~min}$ in Teflon tubes. To obtain $\mathrm{pH} 2$ to $3, \mathrm{H}_{2} \mathrm{SO}_{4}(2 \%$, vol/vol $)$ was added, until the solution turned pink, followed by vortexing for 1 min. After centrifugation at $1,070 \times g$ (Sorvall Super T21, Sorvall Products L.P., Newton, CT) for 5 min at $21^{\circ} \mathrm{C}, 40 \mathrm{~mL}$ of the supernatant was removed to a new tube. Four droplets of $0.1 \% \alpha$-naphtholphthalein indicator resolved in $99 \%$ ethanol were added. Free fatty acids were finally titrated with $0.02 \mathrm{M} \mathrm{KOH}$ resolved in $99 \%$ ethanol (EtOH) until the color turned bluegreen, persisting for a few seconds. All chemicals, if not otherwise indicated, were from Sigma (Sigma-Aldrich Inc., Stockholm, Sweden).

Total milk lipids were methylated according to the procedure of Appelquist (1968) with slight modifications (Johansson et al., 2013b). Milk (10 mL) was mixed with $10 \mathrm{~mL}$ of ethanol and $1 \mathrm{~mL}$ of $\mathrm{H}_{2} \mathrm{SO}_{4}(2.5 \mathrm{~mol} / \mathrm{L})$. Extraction was carried out with $15 \mathrm{~mL}$ of ether:heptane $(1: 1, \mathrm{vol} / \mathrm{vol})$ in screw-capped centrifuge tubes. After centrifugation at $740 \times g$ (Sorvall Super T21) for $2 \mathrm{~min}$ at $25^{\circ} \mathrm{C}$, the upper solvent layer was transferred to a new conical flask containing $1 \mathrm{~g}$ of anhydrous $\mathrm{Na}_{2} \mathrm{SO}_{4}$ to adsorb residual water. The extraction procedure was repeated twice with $10 \mathrm{~mL}$ of ether:heptane $(1: 1, \mathrm{vol} /$ vol). The solvent was evaporated under nitrogen gas. The lipid content of the milk was determined from this total extracted lipid, which was dissolved in hexane and stored at $-80^{\circ} \mathrm{C}$ until analysis. All samples were extracted in triplicate. Changes in the lipid classes during incubation $\left(37^{\circ} \mathrm{C}\right)$ of UHT milk inoculated with the different bacterial species were evaluated using high-performance TLC coupled with the ATS4 Camag (Camag, Muttenz, Switzerland) lipid class analysis procedure. Total lipids were separated and quantified as described by Dutta and Appelqvist (1989). Thinlayer chromatography was performed using precoated glass silica gel TLC plates $(20 \times 20 \mathrm{~cm}$; Silicagel 60 ; 0.20-mm layer, Merck, Darmstadt, Germany) and hexane:diethyl ether:acetic acid (85:15:1, vol/vol/vol) along with reference samples. The lipid samples $(1 \mu \mathrm{g} /$ $\mu \mathrm{L}$ of hexane) were applied to the TLC plate using Camag TLC sampler 4 (Camag) and separated in a $20 \times 20$ twin through chamber (Camag) using $25 \mathrm{~mL}$ of the mobile phase, hexane:diethyl ether:acetic acid (85:15:1, vol/vol/vol). The plates were removed from the chamber after developing $6.9 \mathrm{~cm}$ from the baseline. For derivatization, $20 \mathrm{~g}$ of phosphomolybdic acid in $200 \mathrm{~mL}$ of ethanol was applied for $10 \mathrm{~min}$ at $120^{\circ} \mathrm{C}$. The plates were scanned using a Camag TLC scanner 3 (Camag) to identify the lipid classes. Phospholipids, diacylglycerols, triacylglycerols, cholesterol, sterol esters, and FFA were identified using external 16-1 A and $\mathrm{C} 18-5$ TLC standards (Nu-Chek Prep Inc., Elysian, MN).

For the statistical part, ANOVA was performed with SAS v. 9.3 (SAS Institute Inc., Cary, NC). Least squares means were calculated with the general linear model procedure. The model included the effect of treatment. The option PDIFF (probability difference) was used to estimate the differences among least squares means.

Changes in milk $\mathrm{pH}$ and total number of bacteria in the bacteria-free control milk and milk inoculated with Staph. aureus and Strep. agalactiae, respectively, were recorded at different time points. The $\mathrm{pH}$ was slightly reduced in the buffered milk samples after $6 \mathrm{~h}$ of incu- 
bation with the respective mastitis pathogen ( $\mathrm{pH}$ 6.53), whereas $\mathrm{pH}$ in the bacteria-free control milk remained at 6.69 after $6 \mathrm{~h}$ (data not shown). The 2 bacteria species did not significantly differ with respect to bacterial growth and cfu. At $6 \mathrm{~h}$ of incubation both bacteria reached a stationary phase at $10^{9} \mathrm{cfu} / \mathrm{mL}$ (Figure 1), whereas the bacteria-free control milk had no growth. These results are in agreement with our previous study in which we investigated the proteolytic ability of the same Staph. aureus strain, using the time points $0.5,1$, 2,4 , and $6 \mathrm{~h}$ after inoculation (Johansson et al., 2013a).

Saeman et al. (1988) showed that milk protein degradation initiates already in the udder between milkings, but to our knowledge no similar reports exist on degradation of milk fat. Two methods, TLC and the extraction-titration method, were used for evaluation of the lipolytic effects of Staph. aureus and Strep. agalactiae on milk fat with respect to FFA formation. In both cases the effects of the bacteria on milk fat during incubation were compared with bacteria-free control milk. The extraction-titration method showed accumulation of FFA during incubation of milk samples with mastitis pathogens, whereas there was no change with regard to FFA in the bacteria-free control milk (Figure 2). Accumulation of FFA was verified by the TLC method. After $2 \mathrm{~h}$ of incubation, levels of FFA had increased by 42 and $40 \%$ in samples inoculated by Staph. aureus and Strep. agalactiae, respectively, and after $6 \mathrm{~h}$, by $47 \%$ compared with the bacteria-free control milk (Table 1). The FFA levels of bacteria-free control milk were unaffected during the incubation. The FFA content of milk fat is commonly between 0.5 and $1.2 \mathrm{mmol} / 100$ g (Hanus et al., 2008). Sensory evaluation based on flavor scores by Pillay et al. (1980) showed significant differences between reference milk samples, indicating that the sensory threshold for rancid flavor lies in the range of $4.5 \mathrm{mmol} / 100 \mathrm{~g}$ of fat. Results in this study showed FFA levels exceeding the sensory threshold at 3 and $4 \mathrm{~h}$ after inoculation with Staph. aureus and Strep. agalactiae, respectively (Figure 2).

The diacylglycerols and the phospholipids increased significantly during incubation (Table 1). In milk, phospholipids have been reported to constitute 0.5 to $1.0 \%$ of the milk fat, although we found that the phospholipid fraction in the control milk was about $2 \%$. Most phospholipids are found in the milk fat globule membrane but also in protein and membrane fragments in solution (Fox and McSweeney, 2006). Phospholipids are also the main lipid component of bacterial membranes. Zhang and Rock (2008) showed that bacteria could modulate their membrane properties changing the types of FA or changing the types of polar head groups leading to an altered set of phospholipids. This could be the case of Strep. agalactiae, where we observed an

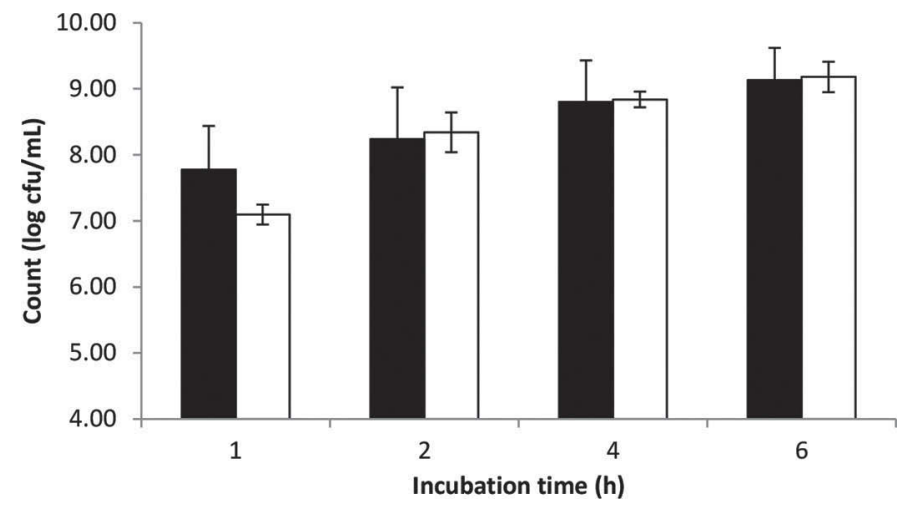

Figure 1. Staphylococcus aureus and Streptococcus agalactiae counts in milk after incubation at $37^{\circ} \mathrm{C}$ for $1,2,4$, and $6 \mathrm{~h}$, respectively. Staphylococcus aureus (black) and Strep. agalactiae (white) were cultured in bacteria-free, UHT-processed milk with $0.1 M$ 3-morpholino-propanesulfonic acid to prevent acidification during incubation. Bars indicate mean \pm standard deviation $(\mathrm{n}=3)$.

increase in phospholipids after 6 h. Undoubtedly, Strep. agalactiae may have contributed to the total amount of phospholipids in the inoculated milk. In milk inoculated with Staph. aureus, on the other hand, the same increase in phospholipids was observed already after 2 h. However, after $6 \mathrm{~h}$ the total amount of phospholipids had decreased by $8 \%$ compared with the previous time point $(2 \mathrm{~h})$. Possibly, Staph. aureus modulates the available phospholipids in this growth phase, resulting in a decrease of the total amount of these lipids (Table 1). Nevertheless, at $6 \mathrm{~h}$ of incubation the amount of

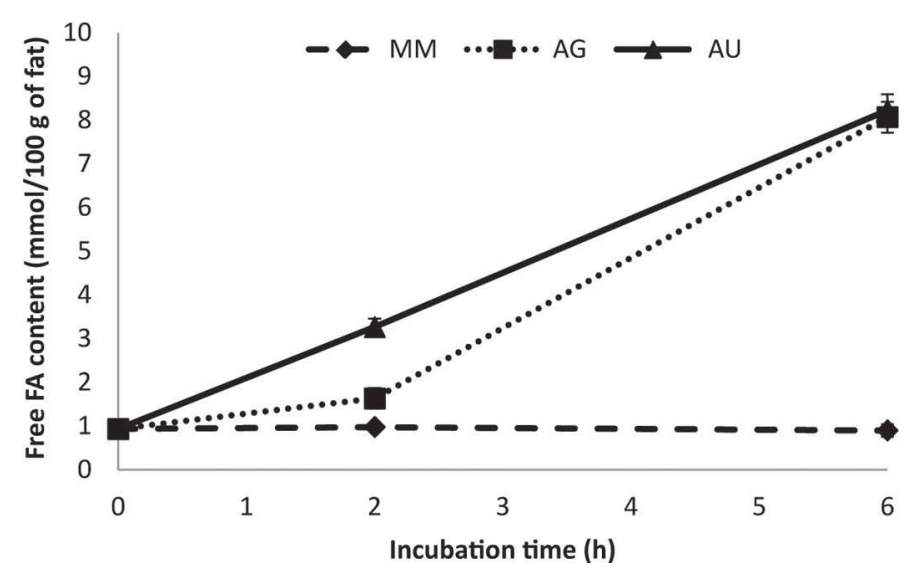

Figure 2. Lipolytic effect of Staphylococcus aureus and Streptococcus agalactiae measured as the formation of FFA by the extraction-titration method. The bacteria were cultured at $37^{\circ} \mathrm{C}$ in bacteria-free, UHT-processed milk with $0.1 M$ 3-morpholino-propanesulfonic acid to prevent acidification during incubation. Milk samples were analyzed at the time of inoculation and after 3 and $6 \mathrm{~h}$ of incubation. $\mathrm{MM}=$ bacteria-free control milk; AG = milk inoculated with Strep. agalactiae; $\mathrm{AU}=$ milk inoculated with Staph. aureus. The FFA content is in $\mathrm{mmol} / 100 \mathrm{~g}$ of fat \pm standard deviation $(\mathrm{n}=3)$. 
Table 1. Effects of Staphylococcus aureus and Streptococcus agalactiae on lipid composition as determined by high-performance, thin-layer chromatography after incubation at $37^{\circ} \mathrm{C}$ for 2 and $6 \mathrm{~h}^{1}$

\begin{tabular}{|c|c|c|c|c|c|c|}
\hline Lipid $^{2}$ & Control milk ${ }^{3}$ & $\begin{array}{c}\text { Milk with } \\
\text { Staph. aureus } \\
2 \mathrm{~h}^{4}\end{array}$ & $\begin{array}{c}\text { Milk with } \\
\text { Staph. aureus } \\
6 \mathrm{~h}^{4}\end{array}$ & $\begin{array}{c}\text { Milk with } \\
\text { Strep. agalactiae } \\
2 \mathrm{~h}^{4}\end{array}$ & $\begin{array}{c}\text { Milk with } \\
\text { Strep. agalactiae } \\
6 \mathrm{~h}^{4}\end{array}$ & $P$-value \\
\hline PL & $2.12 \pm 0.08^{\mathrm{c}}$ & $2.70 \pm 0.11^{\mathrm{a}}$ & $2.50 \pm 0.04^{\mathrm{b}}$ & $2.52 \pm 0.03^{\mathrm{b}}$ & $2.75 \pm 0.06^{\mathrm{a}}$ & $<0.001$ \\
\hline CL & $6.41 \pm 1.48^{\mathrm{a}}$ & $4.10 \pm 0.31^{\mathrm{c}}$ & $4.15 \pm 0.18^{\mathrm{c}}$ & $4.92 \pm 0.09^{\mathrm{b}}$ & $4.87 \pm 0.28^{b}$ & $<0.001$ \\
\hline SES & $5.65 \pm 0.47^{\mathrm{a}}$ & $0.49 \pm 0.11^{\mathrm{c}}$ & $0.68 \pm 0.52^{\mathrm{c}}$ & $1.74 \pm 0.34^{\mathrm{b}}$ & $1.06 \pm 0.23^{\mathrm{c}}$ & $<0.001$ \\
\hline TG & $79.37 \pm 0.80^{\mathrm{d}}$ & $82.95 \pm 0.51^{\mathrm{a}}$ & $80.72 \pm 1.47^{\mathrm{c}}$ & $81.37 \pm 0.42^{\mathrm{bc}}$ & $82.34 \pm 0.37^{\mathrm{ab}}$ & $<0.001$ \\
\hline
\end{tabular}

${ }^{\mathrm{a}-\mathrm{d}}$ Values within a row with different superscript letters are significantly different $(P<0.05)$.

${ }^{1}$ The bacteria were cultured in bacteria-free, UHT-processed milk with $0.1 M$ 3-morpholino-propanesulfonic acid to prevent acidification during incubation.

${ }^{2} \mathrm{PL}=$ phospholipids, $\mathrm{DG}=$ diacylglycerols, $\mathrm{CL}=$ cholesterol, $\mathrm{SES}=$ sterol esters, $\mathrm{TG}=$ triacylglycerols.

${ }^{3}$ Values indicate mean of lipids ( $\%$ of total fat $) \pm \mathrm{SD}(\mathrm{n}=6)$ in bacteria-free control milk after incubation for 0,2 , and $6 \mathrm{~h}$ at $37^{\circ} \mathrm{C}$.

${ }^{4}$ Values indicate mean of lipid class (\% of total fat $) \pm \mathrm{SD}(\mathrm{n}=3)$.

phospholipids had increased significantly in the case of both pathogens compared with the control milk.

It is more difficult to explain the slight increase in TG in combination with a significant increase in DG during incubation. Triacylglycerides are a common lipase substrate, and one would expect an increase in DG and FFA and a decrease in TG as results of lipolysis. All eukaryotic organisms and even some prokaryotes have the ability to synthesize TG. Olukoshi and Packter (1994) suggested that the bacterial diacylglycerol acyltransferase enzyme is probably responsible for the switch of the membrane phospholipids to triacylglycerols during the log phase. This could be the reason for the slight increase of these lipids over time. If Staph. aureus and Strep. agalactiae would be able to synthetize TG, then the milk lipids could be a source of the FFA, whereas the bacterial TG could lead to the slight increase in this fraction. However, to verify this observation, fractionation of endogenous and bacterial TG would be needed.

Moreover, many bacteria have the ability to metabolize steroid compounds such as cholesterol and sterol esters. Sterol esters include esters of cholesterol and FA, with lower solubility in water than cholesterol. They are hydrolyzed to cholesterol and FFA (Ferrier et al., 2011) and can be degraded by microorganisms (Ouf et al., 2012). This is in agreement with our results, where sterol esters decreased and FFA increased during incubation, however, without a concomitant increase in cholesterol. Recently, Kulkarni et al. (2013) showed that some bacteria in milk have the ability to degrade cholesterol, which perhaps could explain why cholesterol decreased during the incubation, that is, the formed cholesterol was used as a substrate and further degraded by Staph. aureus and Strep. agalactiae. Importantly, in this work we could not distinguish between FFA originating from hydrolysis of milk fat by microbial lipases and FA of bacterial origin. We are confident that the increase in FFA in the milk inoculated with mastitis pathogens will largely originate from microbial activity on the milk lipids, but we cannot exclude that microbial synthesis of FA may have contributed to increasing levels of FFA during incubation. In future studies it will be important to measure the initial levels of different lipid classes and not only FFA levels at the time of inoculation to have an indication of the extent to which bacterial load affects lipid profile.

In conclusion, the accumulation of FFA in the samples inoculated by Staph. aureus and Strep. agalactiae suggests their lipolytic activity on milk fat. Mechanisms behind the observed changes in lipid classes in milk inoculated with bacteria need further investigations. Lipolysis of milk fat by mastitis pathogens is likely to take place in the infected mammary gland at high counts of bacteria, and thus, mastitis bacteria are likely to contribute to raw milk deterioration.

\section{ACKNOWLEDGMENTS}

The authors thank colleagues at the National Veterinary Institute (SVA) in Uppsala, Sweden, for kindly sharing the field strains of Staph. aureus and Strep. agalactiae collected in their research. This study was kindly supported by the Faculty of Natural Resources and Agricultural Sciences, Swedish University of Agricultural Science, Uppsala, Sweden.

\section{REFERENCES}

Åkerstedt, M., E. Wredle, V. Lam, and M. Johansson. 2012. Protein degradation in bovine milk caused by Streptococcus agalactiae. J. Dairy Res. 79:297-303.

Appelquist, L.- $\AA$. 1968. Rapid methods of lipid extraction and fatty acid methyl ester preparation for seed and leaf tissue with special remarks on preventing accumulation of lipid contaminants. Royal Swedish Acad. Sci. 28:551-570. 
Deeth, H. C. 2006. Lipoprotein lipase and lipolysis in milk. Int. Dairy J. $16: 555-562$

Dutta, P. C., and L. Å. Appelqvist. 1989. The effects of different cultural conditions on the accumulation of depot lipids notably petroselinic acid during somatic embryogenesis in Daucus carota L. Plant Sci. 64:167-177.

Ferrier, R., A. Harvey, and R. Denise. 2011. Lippincott's Illustrated Reviews, Biochemistry. 5th ed. Wolters Kluwer Health, Philadelphia, PA.

Fox, P. F., and P. McSweeney. 2006. Advanced Dairy Chemistry. Vol. 2 Lipids. 3rd ed. Springer-Verlag, New York, NY.

Haddadi, K., F. Moussaoui, I. Hebia, F. Laurent, and Y. Le Roux. 2005. E. coli proteolytic activity in milk and casein breakdown. Reprod. Nutr. Dev. 45:485-496.

Hanus, O., J. Vegricht, J. Frelich, A. Macek, M. Bjelka, F. Louda, and L. Janu. 2008. Analysis of raw cow milk quality according to free fatty acid contents in the Czech Republic. Czech J. Anim. Sci. $53: 17-30$

Hogan, J. S., R. N. Gonzales, R. J. Harmon, S. C. Nickerson, S. P. Oliver, and K. L. Smith. 1999. Laboratory Handbook on Bovine Mastitis. Natl. Mastitis Counc. Inc., Madison, WI.

Jensen, R. G., and D. S. Newburg. 1995. Bovine milk lipids. Pages 543-575 in Handbook of Milk Composition. R. G. Jensen, ed. Acad. Press, London, UK.

Johansson, M., M. Åkerstedt, S. Li, G. Zamaratskaia, and Å. Lundh. 2013a. Casein breakdown in bovine milk by a field strain of Staphylococcus aureus. J. Food Prot. 76:1638-1642.

Johansson, M., O. Placha, J. Pickova, A. Andrén, G. Zamaratskaia, E. Spörndly, and M. Åkerstedt. 2013b. Impact of crude protein content in silage and concentrate on protein and fatty acid profiles in bovine milk. Czech J. Anim. Sci. 58:303-312.

Keefe, G. P. 1997. Streptococcus agalactiae mastitis: A review. Can. Vet. J. 38:429-437.

Kulkarni, N. S., A. P. Lokhande, R. R. Pachori, P. N. Agrawal, and J. M. Dalal. 2013. Screening of the cholesterol degrading bacteria from cow's milk. Cur. Res. Microb. Biotech. 1:92-94.

Leitner, G., O. Krifucks, U. Merin, Y. Lavi, and N. Silanikove. 2006. Interactions between bacteria type, proteolysis of casein and physico-chemical properties of bovine milk. Int. Dairy J. 16:648-654.

Lu, T., J. Y. Park, K. Parnell, L. K. Fox, and M. A. McGuire. 2012 Characterization of fatty acid modifying enzyme activity in staph- ylococcal mastitis isolates and other bacteria. BMC Res. Notes $5: 323-334$.

Olukoshi, E. R., and N. M. Packter. 1994. Importance of stored triacylglycerols in Streptomyces: Possible carbon source for antibiotics. Microbiology 140:931-943.

Ouf, S. A., A. Q. Alsarrani, A. A. Al-Adly, and M. K. Ibrahim. 2012 Evaluation of low-intensity laser radiation on stimulating the cholesterol degrading activity: Part I. Microorganisms isolated from cholesterol-rich materials. Saudi J. Biol. Sci. 19:185-193.

Pillay, V. T., A. N. Myhr, and J. I. Gray. 1980. Lipolyses in milk. Determination of free fatty acid and threshold value for lipolyzed flavor detection. J. Dairy Sci. 64:1213-1218.

Politis, I., K. F. Ng Kwai Hang, and R. N. Giroux. 1989. Environmental factors affecting plasmin activity in milk. J. Dairy Sci. 72:1713-1718.

Riffon, R., K. Sayasith, H. Khalil, P. Dubreuil, M. Drolet, and J. Lagacé. 2001. Development of a rapid and sensitive test for identification of major pathogens in bovine mastitis by PCR. J. Clin. Microbiol. 39:2584-2589.

Rosenstein, R., and F. Götz. 2000. Staphylococcal lipases: Biochemical and molecular characterization. Biochimie 82:1005-1014.

Saeman, A. I., R. J. Verdi, D. M. Galton, and D. M. Barbano. 1988. Effect of mastitis on proteolytic activity in bovine milk. J. Dairy Sci. 71:505-512.

Salih, A. M. A., M. Andersson, and B. Tuckley. 1977. The determination of short- and long-chain free fatty acids in milk. J. Dairy Res. 44:601.

Shipe, W. F., G. F. Senyk, and K. B. Fountain. 1980. Modified copper soap solvent extraction method for measuring free fatty acids in milk. J. Dairy Sci. 63:193-198.

Sørhaug, T., and L. Stepaniak. 1997. Psychrotrophs and their enzymes in milk and dairy products: Quality aspects. Trends Food Sci. Technol. 8:35-41.

Teh, K. H., S. Flint, J. Palmer, D. Lindsay, P. Andrewes, and P. Bremer. 2011. Thermo-resistant enzyme-producing bacteria isolated from the internal surfaces of raw milk tankers. Int. Dairy J. $21: 742-747$

Zhang, Y. M., and C. O. Rock. 2008. Membrane lipid homeostasis in bacteria. Natl. Rev. Microbiol. 6:222-233. 